\title{
The Narration and Forecast of Overseas Municipal Solid Waste Management Research
}

\author{
Lin-Lin XUAN ${ }^{1, a,{ }^{*}}$, Min LING ${ }^{2, b}$ \\ ${ }^{1}$ China, Heilongjiang province, Harbin, Harbin University of commerce, Finances and Public \\ Administration academy, China \\ ${ }^{2}$ China, Heilongjiang province, Harbin, Harbin University of commerce, Finances and Public \\ Administration academy, China \\ a911076878@qq.com, b73276972@qq.com \\ ${ }^{*}$ Corresponding author
}

Keywords: Municipal solid waste management(MSWM), Waste generation, Waste collection, Waste disposal.

\begin{abstract}
Municipal solid waste management (MSWM) problem is a issue that every country must face. Through a summary of the research results as you can see, municipal solid waste management in the developed countries is superior to the developing countries. This article summarizes the process of MSWM abroad, including generation, collection and disposal of municipal solid waste, while summarizes current research progress of MSW management abroad, and put forward some directions for future research on municipal solid waste management.
\end{abstract}

\section{Introduction}

Solid waste (trash or garbage in US, refuse or rubbish in UK) refers to people who generate solid waste in their daily lives or provide services for daily life activities. With the growth of the world's population and the rapid development of economy, particularly in developing countries, governments of all countries are increasingly attach important to municipal solid waste management issues. In two cities-London and Kumasi, for example. In 2006, the MSW emissions in London per household per day is $1.2 \mathrm{~kg}$, while the emissions in Kumasi is $0.6 \mathrm{~kg}$. Althought the trash volume in Kumasi is lower than London, its population is larger than the total population in London. Therefore, compared with developed countries, municipal solid waste management in developing countries the problem is even more severe. For developing countries, sustainable municipal solid waste management system is necessary [1].

Due to differences in levels of economic development, waste management problems faced by States is also different. This article summarizes the process of MSWM abroad, including generation, collection and disposal of municipal solid waste, while summarizes current research progress of MSW management abroad, and put forward some directions for future research on municipal solid waste management.

\section{Research on MSW Generation Management}

With rapid economic development, population growth and changes in people's consumption habits, quantity and composition of municipal solid waste emissions are constantly changing. Overall trend is growing waste emissions and waste constituents are increasingly complex. Generally speaking, due to developed countries have been carried out some policies such as waste reduction, waste emissions are brought under control. On the contaray, and waste emissions in developing countries showed a rising trend. In addition, waste components between developed and developing countries is also different. In developed countries, organic waste is more lower than developing countries. 


\section{Research on Waste Reduction}

With growing volumes of MSW, almost all states made their policy toward waste reduction. Policymakers are increasingly aware potential role of waste reduction to solve the waste problem [2].Scholars from different countries research on how to achieve waste reduction from different point of view. Mainly in the following three views:

Clarified and extended producer's responsibility. Extended producer responsibility is a powerful policy tool, it can not only affect the Government's management of the raw materials, but also can effectively mitigate environmental pollution. To some extent, it also reflects the "polluter pays principle", eased fiscal pressure of the Government. Clear is that clarified and extended producer responsibility must through the whole product life cycle [3], which not only includes product liability, but also includes the responsibility during the use process and after the process. Clear that the main body of implementation of extended producer responsibility is government, and the main means is legislation [4]. Government must develop detail legal norms to restrain producers's behavior.

Pay attention to citizens ' participation. Waste reduction needs citizens ' involvement, however, citizen's willingness of participation in developing countries is generally not very high, and they always have littering habits [5].There are many ways of increasing citizens ' sense of participation, including environmental education and by means of legal supervision. More specifically measures as follows: household compost, buying toothpaste without toothpaste boxes, using handkerchief, buying product with big packaging as well as to bring their own shopping bag when shopping in the market [2].

The importance of waste recycling operations. Recycling has the dual benefits of environmentally and economically, developed countries stressed the environmental benefits, while developing countries stressed the economic gains[6]. Waste recycling is a part of waste reduction [7]. For example, in 1996, Hong Kong through recycling gains approximately 1.65 million tons of raw materials of garbage work, it accounts for 36 per cent of all municipal solid waste [6]. Recycling of garbage work can draw on the experience of developed countries or regions or through legislative means to extended producer's responsibility [8], or let the producer to pay a fee, and the government can organize specialized recycling work.

In addition, decrease the number of often associated with reducing or limiting emissions of toxic waste [2]. For those enterprises that produce toxic products, taxes or other ways to be limited and for individual residents, to try to encourage them to buy environmentally friendly products, such as batteries that can be charged more than once.

\section{Research on Waste Composition}

Due to different living habits and the levels of economic development, the composition of different countries are different. In General, the waste generated in developed countries have a low organic composition while the percentage is more higher in developing countries. In Asia, many developing countries have a high percentage of organic waste, even in the same region, content of organic waste is also different. Is is mainly depend on the type of housing and lifestyle. [9]

\section{Research on Waste Collection Management}

Most developing countries are still faced with the problems of waste collection, $3 \%$ 15\% of municipal budget is spent on waste collection, so it does not have sufficient funding for recovery, treatment and sanitary landfill. [12] Waste collection is also an important aspect of MSWM. Waste collection has different ways in different countries, while functions which governments undertake are also different. In generally, collection rates in developing countries are usually not high, and waste classification is not enough. This is mainly due to the lack of funds and irrational waste management facilities. [5]

\section{Research on Waste Sorting Management}

The efficiency of MSWM depends on the waste sorting work at the source[11]. On the waste 
sorting work, developed countries is represented by Japan. $\mathrm{n}$ Japan waste sorting work is extremely detailed, and finalized by the way of legislation. Some scholars that it is necessary to establish a waste sorting and recovery market [12 13], which is actually an incentive mechanism, that is, through economic instruments to encourage waste sorting behavior.

In addition, waste sorting require corresponding sorting facilities, the government should let the public know how to use these facilities and, if necessary, may indicate the way of waste sorting on the sorting facility. For citizens that don't comply with the regulations, governments can use a reporting system and let the citizens who report it get some reward. Thus, it can constraints on people's behavior [12]. Meanwhile, for those people who undertake waste sorting work, technical coaching is needed.

\section{Research on Waste Transportation}

After the waste sorting work, the waste need a certain way of collection and transportation. Some countries take targeted location to collect waste, that is, at the prescribed time, and location (Generally on both sides of the road), there are special refuse collection vehicles to collect the garbage .There also have country undertake home collection, that is, by a dedicated staff in charge of waste collection orperate door to door collection. No matter what kind of ways, waste collection and transportation needs the participation of government, business, other social organizations and citizens. However, garbage collecting transportation in most developing countries mainly depend on government, other organizations and individual citizens do not play an appropriate role in a number of countries, even if there are other organizations involved, they did not cooperate well with local residents and the government [9], resulting in inefficiencies.

The government should guide residents on how to throw different types of garbage in the process of Garbage collection on transportation and how to choose the location of waste collection facilities and enhance the technology content of waste collection facilities [1]. If necessary, government should supervise its implementation by means of legislation.

\section{Research on Waste Disposal Management}

\section{Research on Waste Disposal Method}

There are a lot of ways of waste disposal, including: landfill, compost and incineration. According to their own economic development and waste components, different countries and regions choose different approaches. But at first simple stacking and landfill was the dominated method. With the development of economy, developed countries had already abandoned dumps and landfill approaches, while increasingly use incineration and landfill only as an aid. In many developing countries, due to the incineration method requires a lot of capital investment, and higher demands on technology, so the landfill is still the main way of waste disposal. Therefore, developing countries facing more environmental crisis.

The management of garbage disposal, some scholars claim "radish and stick" type of management. Through a levy on landfill called "landfill tax" to increase the cost of landfill disposal, and encouraged the adoption of an alternative of landfill such as incineration. At the same time, increase subsidies to other waste treatment methods [14]. However more scholars advocate a holistic way of waste disposal, using various of waste disposal methods and techniques, and building an integrated mode instead of simple landfill. Landfill merely as a supplementary means of garbage disposal, that is, when there is no other way of waste disposal, landfill can be an alternative method[14].

\section{Research on Waste Disposal Mode of Operation}

As the waste disposal industry involved technical, economic and environmental factors, if it rely solely on the government, there is on doubt that government may have financial burden. Public-Private Partnership(PPP) has been used as a waste management model in many countries. This may not only ease the financial burden of the Government, but also improve the quality of 
service [11]. For example ,Singapore is a fairly typical of waste management privatization.

In many developing countries, waste disposal is still dependent on Government, privatization is not enough. Many waste disposal business do not have a clearly goals and have organizational confusion [14]. Many garbage disposal companies pursue for profit-making purposes only, it leads to a selective disposal phenomenon [6]. So, the Government has the responsibility to regulate waste disposal businesses or institutions to ensure that they are able to meet the requirements of laws and regulations. Meanwhile, government should also encourages the establishment of regional waste disposal facilities, and set a serious of long-term waste disposal policies, which reflect sustainable development idea.

\section{Research on the Analysis Methods of Municipal Solid Waste Management System of Foreign Countries}

MSWM system is an integrated and complex system, a good MSWM can't live without a reasonable municipal solid waste management system. At present, the trends in municipal solid waste management in foreign countries is to establish an integrated municipal solid waste management systems, ensuring that every aspects of MSWM can coordinate rationally.

To pursue a proper municipal waste management system, it must involves some analysis methods. Main analysis methods include:(1) Multi-criteria analysis method. Multi-criteria Analysis is a method that considering all the aspects of MSWM including financial, technical, economic, ecological and social factors. After that, selecting one system that suits the local solid waste management situation. (2) Multivariate linear regression method. This method is primarily used for data analysis, and these data are acquired in specific waste management activities, such as population density, the amount and the proportion of waste emissions of different regions and so on. (3) Risk analysis method. This method is primarily used to analyze risks in waste management issues, such as noise, traffic congestion and other problems in transport. (4) System analysis method. This method regard MSWM as an integrated dynamic system, every aspects of this system is a subsystem such as waste generation and so on. Through analysis and integration, thus provide a valuable perspective for municipal solid waste management.

\section{Outlook of Future Research of MSW}

Municipal solid waste through the consolidation of existing research results, we can conclude that municipal solid waste management issues are valued by almost all the countries. Foreign scholars attach great importance to the significance of the municipal solid waste management.

With the rapid development of the global economy, municipal solid waste management of the world becomes more and more important. Based on the current study flaws, in order to further expand the breadth and depth of research on municipal solid waste management, it still needs further study .

\section{Strengthen regional cooperation for MSWM research}

Governments should pay more attention to the cooperation in whole country or in certain region and develop the policy that can throughout all the regions. No matter waste reduction, waste sorting, waste collection and transportation or waste disposal, it may have some restrictions without cooperation. So strengthen regional cooperation for the management of municipal solid waste is a trend;

\section{Strengthen the executive ability of local government}

It can be said that municipal solid waste management function is mainly undertake by local governments. Local government must consider the actual situation of the region and combine it with national strategy effectively. Meanwhile, government must avoid policy executive deviation.

Increase the quantitative study of MSW

Municipal solid waste management is a complex task for involving a number of indicators. If we just use qualitative analysis methods, we always can't get desired effect. In future, waste management research should know how to apply quantitative analysis methods, especially for the 
research in developing countries, because waste management problems are more severe in developing countries.

\section{Conclusion}

In the current context of rapid economic development, both developed and developing countries can't avoid municipal solid waste management issues. Good municipal solid waste management systems are vital for economic and social development. In particular, some developing countries, because of the level of economic development and the quality of population and other reasons, municipal solid waste management is crucial. Therefore, in every aspect, researching in this area is necessary. It is essential for economic and social development.

\section{Reference}

[1] Mizpah Asase, Ernest K. Yanful, Moses Mensah, Jay Stanford, Samuel Amponsah, Comparison of municipal solid waste management systems in Canada and Ghana:A case study of the cities of London, Ontario, and Kumasi, Ghana,J. Waste Management.29(2009)2779-2786.

[2] Douglas J.Lober,Municipal solid waste policy and public participation in household source reduction,J. Waste Management\&Research.14(1996)125-143.

[3] Kate McKerlie a,Nancy Knight , Beverley Thorpe, Advancing Extended Producer Responsibility in Canada,J. Journal of Cleaner Production .14(2006) 616-628.

[4] Ping Sze Ko · Chi Sun Poon, Domestic waste management and recovery in Hong Kong,J. Mater Cycles Waste Management.11(2009) 104-109.

[5] Ayo Babalola1, Hassan Tsenbeya Ishaku2, Ibrahim Busu1, Mohammad Rafee Majid,The Practice and Challenges of Solid Waste Management in Damaturu, Yobe State, Nigeria,J. Journal of Environmental Protection.1(2010) 384-388.

[6] Shan-shan Chung, Chi-sun Poon, Recovery systems in Guangzhou and Hong Kong,J. Resources, Conservation and Recycling.23( 1998) 29-45.

[7] Hopper, J.R., Yaws, C.L., Ho, T.C., Vickhailak, M,Waste minimization by process modification,J. Waste Management.13(1993) 3.

[8] Li-Teh Lu, Teng-Yuan Hsiao, Neng-Chou Shang, Yue-Hwa Yu, Hwong-Wen Ma,MSW management for waste minimization in Taiwan:The last two decades,J. Waste Management.26(2006) 661-667.

[9] Ai Hiramatsu, Yuji Hara, Makiko Sekiyama, Ryo Honda,Municipal solid waste flow and waste generationcharacteristics in an urban-rural fringe area in Thailand,J. Waste Management \& Research.27(2009) 951-960.

[10] Maryam Masood, Claire Y Barlow,Framework for integration of informalwaste management sector with theformal sector in Pakistan,J.Waste Management \& Research.31(2013) 93-105.

[11] M.A. Massouda,1, M. El-Fadel, A. Abdel Malak, Assessment of public vs private MSW management: a case study,J. Journal of Environmental Management.69(2003) 15-24.

[12] R.M. Espinosa , S. Turpin , G. Polanco , A. De laTorre , I. Delfín , I. Raygoza ,Integral urban solid waste management program in a Mexican university,J. Waste Management.28(2008) 27-32.

[13] A. Imam, B. Mohammed, D.C. Wilson, C.R. Cheeseman, Solid waste management in Abuja, Nigeria,J. Waste Management.28(2008) 468-472.

[14] Adam D. Read, Paul Phillips , Guy Robinson,Landfill as a future waste management option in England: the view of landfill operators,J. Resources, Conservation and Recycling.20( 1997)83-205. 